APR 0 o LUNu

Sta $4 \$ 5$ ENGINEERING DATA TRANSMITTAL

Page 1 of

1. EDT 620317

\begin{tabular}{|l|l|}
\hline $\begin{array}{l}\text { 2. To: (Recelving Organization) } \\
\text { Distribution }\end{array}$ & $\begin{array}{l}\text { 3. From: (Originating Organization) } \\
\text { WESF Engineering }\end{array}$ \\
\hline $\begin{array}{l}\text { 5. Proj./Prog./Dept./Div.: } \\
\text { WM/WESF/Engineering }\end{array}$ & $\begin{array}{l}\text { 6. Design Authority/Design Agent/Cog. Engr.: } \\
\text { S. J. Davis }\end{array}$ \\
\hline
\end{tabular}

8. Originator Remarks:

PERFORM ULTRASONIC TESTING ON CS CAPSULE OVERPACKS

Ultrasonic Testing

10. System/Bidg./Facility:

C11 / 225B / WESF

12. Major Assm. Dwg. No.:

11. Receiver Remarks:

11A. Design Baseline Document? $\bigcirc$ Yes $\bigotimes$ No

CVI 50094

13. Permit/Permit Application No::

14. Required Response Date:

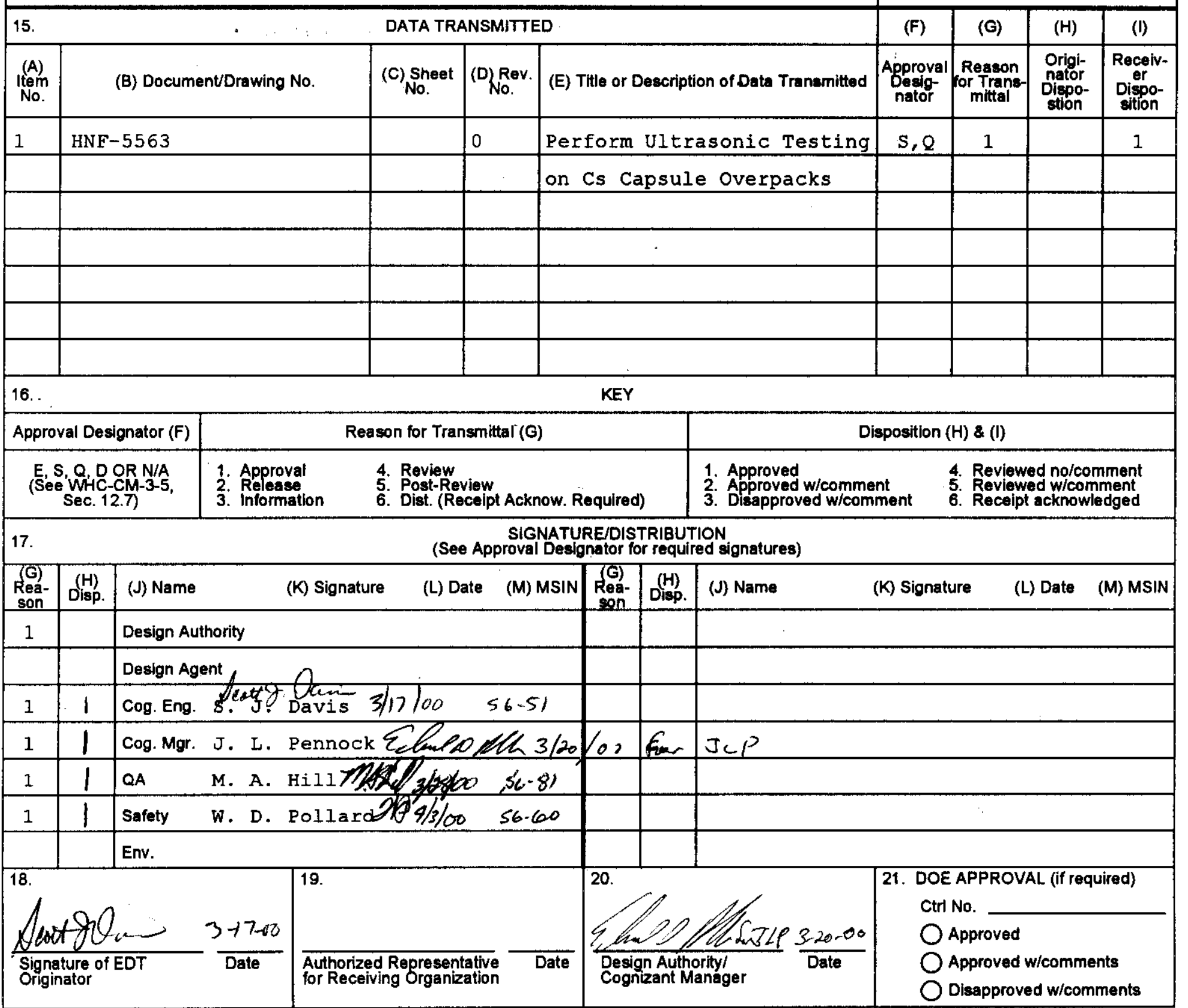


HNF-5563

Revision 0

EDT 620317

\title{
PERFORM ULTRASONIC TESTING ON CS CAPSULE OVERPACKS
}

\author{
S. J. DAVIS \\ FLUOR HANFORD
}

Date Published

April 2000

Prepared for the U.S. Department of Energy

Assistant Secretary for Environmental Management

Project Hanford Management Contractor for the

U.S. Department of Energy under Contract DE-AC06-96RL13200

Fluor Hanford

P.O. Box 1000

Richland, Washington
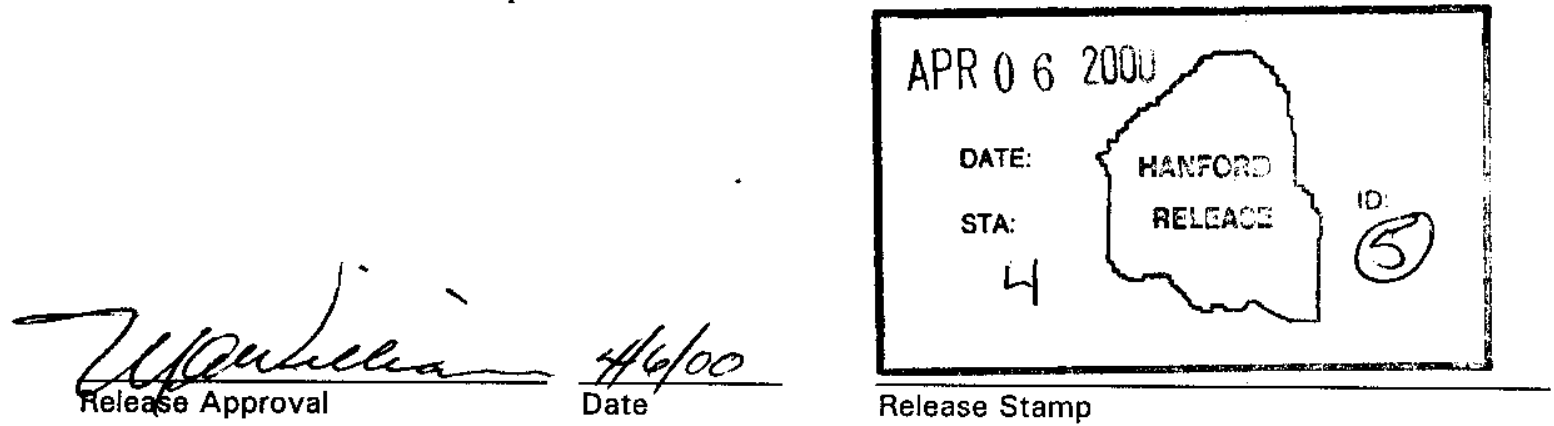


\section{PERFORM ULTRASONIC TESTING ON Cs CAPSULE OVERPACKS}

Prepared for the U.S. Department of Energy

Assistant Secretary for Environmental Management

Project Hanford Management Contractor for the

U.S. Department of Energy under Contract DE-AC06-96RL13200

Fluor Hanford

P.O. Box 1000

Richland, Washington 
TRADEMARK DISCLAIMER

Reference herein to any specific commercial product, process, or service by trade name, trademark, manufacturer, or otherwise, does not necessarily constitute or imply its endorsement, recommendation, or favoring by the United States Government or any agency thereof or its contractors or subcontractors.

This report has been reproduced from the best available copy. Available in paper copy and microfiche.

Available electronically at http://www.doe.gov/bridge. Available for a processing fee to the U.S. Department of Energy and its contractors, in paper, from:

U.S. Department of Energy

Office of Scientific and Technical Information

P.O. Box 62

Oak Ridge, TN 37831-0062

phone: $865-576-8401$

fax: 865-576-5728

email: reports@adonis.osti.gov(423) 576-8401

Available for sale to the public, in paper, from:

U.S. Department of Commerce

National Technical Information Service

5285 Port Royal Road

Springfield, VA 22161

phone: $800-553-6847$

fax: 703-605-6900

email: orders@ ntis.fedworld.gov

online ordering: http://www.ntis.gov/ordering.htm

Printed in the United States of America

Total Pages: $\quad .13$ 


\section{USE TYPE: CONTINUOUS}

\section{OVERPACK TEST PROCEDURE}

WESF

HNF-5563

Revision 0

\section{PERFORM ULTRASONIC TESTING ON Cs CAPSULE OVERPACKS}

Prepared by:

Facility Engineering:

Cogema Inc.
WESF Engineering: S. J. Davis, Engineer

S. J. Davis, System Engineer/Test Engineer

M. A. Hill, Quality Assurance Engineer

C. N. Jackson, NDE Level III UT

W. H. Nelson, NDE Level III UT

Page 1 of 10 


\section{Revision Status}

Change

Number

Date

Change

Document

Page(s)

All
Description

New procedure. 


\subsection{PURPOSE AND SCOPE}

This procedure provides a safe, uniform method for the performance of the ultrasonic weld inspection of the Cesium capsule overpacks. The inspection system will detect cracks, lack of fusion, and lack of penetration. This computer controlled automated system will perform the examination once the capsule overpack has been placed in the pool cell.

Examination of the capsule overpacks will be in accordance with drawing H-2-83014, REV. 0 , and a certified NDE examiner will perform the test procedure, provide analysis, and test documentation.

\subsection{REFERENCES}

2.1 EO-906-003, Transfer and Storage of Capsules

2.2 COGEMA-SVUT-INS-007.2, REV 0, Ultrasonic Test Procedure

2.3 H-2-83014, Rev 0, Cesium Capsule Type-W Calibration Standard

2.4 ASME Boiler and Pressure Vessel Code

\subsection{PERSONNEL REQUIREMENTS}

3.1 Radiological Control Technician (RCT), as required.

3.2 Nuclear Process Operator (NPO), as required.

3.3 System Testing Engineer.

3.4 Cogema Engineering NDE personnel shall be certified to COGEMA-SVQP-014, REV. 0, Qualification and Certification of NDE Personnel.

3.5 Quality Assurance Representative 
4.0 PRECAUTIONS AND LIMITATIONS

4.1 IOSR WARNING - AC 5.10 "Movement of heavy loads over ACTIVE POOL CELLS is prohibited unless performed in according to a recovery plan or an emergency response procedure."

4.2 This is a step-by-step compliance procedure. However, Sections may be performed in any sequence. Steps within each Section may be repeated, or performed out-of-order with the approval of the test director. No step sequence changes shall void previously performed Steps. Steps not required for procedure completion shall be indicated as such by entering "N/A" in the appropriate spaces. An explanation must be provided in the COMMENTS section of the data sheet.

4.3 If during performance of this procedure, any of the following conditions are found, immediately stop work, place equipment in a safe condition, and notify the Configuration Control Authority (CCA), Facility Representative for Capsule Overpack NDE Testing, or designee.

- Any equipment malfunction which could prevent fulfillment of its functional requirements.

- Personnel error or procedural inadequacy which could prevent fulfillment of procedural requirements.

4.4 Contact CCA or designee for additional instructions, if changing plant conditions affect work or delays are anticipated to extend work past end of shift.

4.5 If any waste is generated during performance of this procedure, consult Facility Waste Coordinator for specific instructions to ensure compliance with HNF and DOE environmental standards, as applicable, for disposal.

4.6 Alarms expected to be generated due to performance of this procedure:

- None

4.7 The test fixture will remain submerged in the pool cell until removal is specified by the test director (i.e. for repairs, maintenance or upon completion of tasks). Due to safety authorization basis considerations, prior to performing any heavy load rigging over active pool cells, (such as the installation or removal of the NDE fixture), all capsules must be removed from the affected cell.

4.8 Efforts must be made to minimize exposure time for capsules in the test stand. Radiological exposure will contribute to premature component failure. 


\section{Perform Ultrasonic Testing on Cs Capsule Overpacks}

HNF-5563

REV 0 ,

Page 5 of 10

\subsection{SPECIAL TOOLS, EQUIPMENT, AND MATERIALS}

5.1 Sonix Uitrasonic Test Fixture

5.2 Sonix two channel UT system, including motor controller, computer interface with Flex Scan software, pulsers, and Printer

5.3 Ultrasonic calibration standard

5.4 Capsule Tongs

5.5 Test Barrier Signs/Rope

\subsection{PREREQUISITES}

6.1 Obtain release from CCA prior to beginning performance of this testing activity.

6.2 Capsule overpacks are to be located in Pool Cell 1.

6.3 Overhead crane and catwalk are operable.

6.4 Sonix system is operable.

6.5 UT Equipment is installed in the Pool Cell 12.

6.6 Camera and light systems are operable.

6.7 E0-906-003, Transfer and Storage of Capsules, Attachment A, Engineering Capsule Transfer Plan, has been completed for movement of the capsules. 


\subsection{CAPSULE OVERPACK INSPECTION}

\section{NOTE:}

"Cal" is a generic term identifying calibration of the test standard. This may additionally be considered a "pre-cal" or a "post-cal", depending on whether it was performed before or after the capsule test. Both tests are required to qualify the capsule inspection. Several capsules may be inspected before a "post-cal" is performed. This is at the discretion of the test director.

NDE

7.1 PERFORM Cal as required by COGEMA-SVUT-INS-007.2, REV. 0, Ultrasonic Test Procedure and RECORD in Data Sheet.

NCO

7.2 OBTAIN capsule overpack per EO-906-003.

\section{NOTE}

An overpack identification number is located on the side of the capsule nearest the "Hot End" to aid in identifying the "Hot End".

OPS

7.3 PLACE capsule overpack in test stand as follows:

7.3.1 ORIENT with "Hot End " up.

7.3.2 PLACE in test stand.

7.3.3 CLOSE test stand gate.

QA

7.4 VERIFY and RECORD capsule overpack number and orientation on data sheet using underwater camera system.

NDE

7.5 PERFORM scans per vendor test procedure COGEMA-SVUT-INS-007.2, REV. 0, Ultrasonic Test Procedure. 
NCO

7.6 WHEN scan is completed,

IHEN FLIP capsule overpack as follows:

7.6.1 OPEN test stand gate.

7.6.2 REMOVE and ORIENT with "Cold End " up.

7.6.3 PLACE in test stand.

7.6.4 CLOSE test stand gate.

QA

7.7 VERIFY and RECORD capsule overpack orientation on data sheet using underwater camera system.

NDE

7.8 PERFORM scans per vendor test procedure COGEMA-SVUT-INS-007.2.

NDE

7.9 WHEN an acceptable inspection has been performed,

IHEN RECORD date and Test Record Number on data sheet.

NCO

7.10 WHEN scan is completed,

IHEN REMOVE capsule overpack as follows:

7.10.1 OPEN test stand gate.

7.10.2 REMOVE overpack capsule.

7.10.3 RETURN to storage per EO-906-003.

\section{Test Director/NDE/QA}

7.11 SIGN Data Sheet confirming completion of work.

\section{Test Director/NDE/QA}

7.12 IE additional capsules are to be inspected, IHEN REPEAT Steps 7.1 through 7.10 for each capsule overpack, OTHERWISE GO TO Section 8.0 RESTORATION.

\subsection{RESTORATION}

8.1 IOSR WARNING - AC 5.10 "Movement of heavy loads over ACTIVE POOL CELLS is prohibited unless performed in according to a recovery plan or an emergency response procedure." 


\section{Perform Ultrasonic Testing on Cs Capsule Overpacks}

HNF-5563

REV 0 ,

Page 8 of 10

8.2 Ensure all test equipment has been disconnected and removed.

8.3 No testing labels will be attached to the capsules.

8.4 Remove test fixture from the pool cell, if directed by the test director.

\subsection{TESTING AND ACCEPTANCE}

9.1 The signatures on the attached Data Sheet provide verification of the performance of the Capsule Overpack Ultrasonic Inspection.

\subsection{DISPOSITION}

10.1 Inform CCA or designee testing is complete.

10.2 Record in COMMENTS section of PM/S Data Sheet, Work Request Number(s) of any work documents generated as a result of this instruction, if applicable.

10.3 Return Work Document(s) to Work Control.

\subsection{BIBLIOGRAPHY}

11.1 HNF-CD-WM-IOSR-001, Interim Operational Safety Basis.

11.2 HNF-SD-WM-SEL-008, WESF Safety Equipment List

11.3 ASME Boiler and Pressure Vessel Code, Section V, 1999

11.4 ASNT SNT-TC-1A, 1996

11.5 H-3-307504, Rev 0, Capsule Overpack Drawing

11.6 H-2-83014, Rev 0, Cesium Capsule Type-W Calibration Standard

11.7 HNF-PRO-081, Hazardous Energy Control Program.

11.8 HNF-PRO-083, Personal Protection.

11.9 HNF-PRO-085, Hand and Portable Power Tools.

11.10 HNF-PRO-088, Electrical Work Safety.

11.11 HSRCM-1, Hanford Site Radiological Control Manual, Chapter 2, Part 3, "Posting," and Chapter 3, Part 2, "Work Preparation." 


\section{ULTRASONIC INSPECTION OF THE CAPSULE OVERPACKS - DATA SHEET} (Page 1 of 2)

\section{CALIBRATION TEST TABLE}

\begin{tabular}{|l|l|l|}
\hline \multicolumn{1}{|c|}{$\mid$ Pre-Calibration } & & \\
\hline Post-Calibration & & \\
\hline
\end{tabular}

(QA) Step 7.4

CAPSULE NO:

Orientation:

\begin{tabular}{lll}
1 & & 1 \\
\hline QA Print Name & QA Signature & Date
\end{tabular}

(QA) Step 7.7

Orientation:

1

QA Print Name

QA Signature

Date

(NDE) Step 7.9

Date test performed

Test Record Number

Step 7.11

NDE:

\begin{tabular}{ccc} 
& & 1 \\
\hline Print Name & Signature & Date
\end{tabular}

Quality Assurance Engineer:

Print Name

1

Signature

1

Test Director:

\begin{tabular}{ccc} 
& 1 & 1 \\
\hline Print Name & Signature & Date
\end{tabular}

THINK 
Perform Ultrasonic Testing on Cs Capsule Overpacks

HNF-5563

REV 0,

Page 10 of 10

\section{ULTRASONIC INSPECTION OF THE CAPSULE OVERPACKS - DATA SHEET}

(Page 2 of 2)

Comments:

(Duplicate as required)

THINK R RA INALWEDO 